\title{
Genetic Variability Studies in Fruit Quality Parameters of Kashmiri Cherry (Prunus avium L.)
}

\author{
Jahangeer A. Baba ${ }^{1 *}$, W.M. Wani ${ }^{2}$, R.A. Wani ${ }^{1}$, Umar Iqbal ${ }^{1}$, S.A. Hakeem ${ }^{1}$, \\ Z.A. Dar ${ }^{1}$, Y.A. Basu' ${ }^{1}$, S. Bashir' ${ }^{1}$, S. Nissa ${ }^{1}$, A.Y. Baba ${ }^{1}$, Rafiya Mushtaq ${ }^{2}$, \\ Rehana Javid ${ }^{2}$ and Najeeb Mughal ${ }^{3}$
}

${ }^{1}$ DARS, Budgam, J\&K, India

${ }^{2}$ Division of Fruit Science, Shalimar, Kolkata, India

${ }^{3}$ Faculty of Agriculture, Wadura, Sher-e-Kashmir University of Agricultural Sciences and

Technology Kashmir Shalimar, Srinagar - 192005, J \& K, India

*Corresponding author

\section{A B S T R A C T}

\begin{tabular}{|l|}
\hline Ke y w o r d s \\
Cherry, Genetic \\
variability, Fruit \\
quality, Accessions. \\
\hline Article Info \\
\hline $\begin{array}{l}\text { Accepted: } \\
\text { 17 September } 2017 \\
\text { Available Online: } \\
\text { 10 November } 2017\end{array}$ \\
\hline
\end{tabular}

\section{Introduction}

Sweet cherry belongs to the genus Prunus along with almonds, peaches, plums and apricots. The edible portion consists of the outer layer of the mature ovary wall, the flesh (mesocarp) and the skin (exocarp). The pit (endocarp) encloses the seed. Sweet cherry is a vigorous tree with strong apical control with an erect pyramidal canopy shape; grows up to
$18 \mathrm{~m}$ in wild but in cultivated form, sweet cherries are maintained up to $4 \mathrm{~m}$ in height. Leaves are relatively large, elliptic with acute tips, petiole and strongly veined (1). Sweet cherry trees generally have larger leaves and bear larger fruit than sour cherries and have a markedly sweeter taste. The sweet cherry fruit is described as dark or light according to skin 
color. The skin color of dark cherries range from reddish-purple to mahogany; for light cherries, skin color ranges from yellow to yellow with a pink blush.

Cherry cultivation is mainly confined between $35^{\circ} \mathrm{N}$ and $55^{\circ} \mathrm{S}$ latitude. However in some exceptional areas like Norway, the main cherry growing areas are located at $60^{\circ} \mathrm{N}$ latitude (2). The areas having good winter rains and dry cool summers are ideal for cherry cultivation. Southern hill slopes with adequate air drainage are preferable sites. The Jammu and Kashmir State is located in the North most part of India between $32^{0}-17^{\prime}$ to $37^{\circ}-06^{\prime}$ latitude, $73^{\circ}-26^{\prime}$ and $80^{\circ}-38^{\prime}$ East longitude and $81^{0}$ East Greenwich falling in western Himalayas region of the country. The geographical area of 233 lakh square $\mathrm{Km}$ comprises mainly of mountainous tract out of which about 24 lakh hectares encompasses agriculture (3).

By virtue of temperate climatic conditions of Kashmir valley, 90 per cent of the total cherry production of India is confined to Kashmir valley of Jammu and Kashmir (4) In India, cherry is mainly grown in the state of Jammu and Kashmir, Himachal Pradesh and a very little acreage in Uttarakhand (5) Under Kashmir conditions, cherries attain market maturity within 60 to 70 days after full bloom and are the first temperate tree fruits to reach the market fetching premium price. In Kashmir valley Bigarreau Napolean (Double Glass), Bigarreau Noir Gross (Misri), Black Heart (siyah Gol), Pourpera Perceca (Awal Number), Guigne Noir Gross Lucenta (Tontal) and Guigne Noir Hative (Makhmali) are the most common sweet cherry cultivars cultivated in plains, foot hills and upland areas (6). The state of Jammu and Kashmir is bestowed with wide range of agro-climatic conditions that offers tremendous scope for cultivation of both temperate as well as subtropical fruits. The valley of Kashmir has a distinction and is comparable to any other state in the country, producing all kinds of temperate fruits. The favorable agro-climatic conditions and the active involvement of the people in fruit farming have been responsible in the increased production of the fruits since independence. Almost 2-3 million people of the state are directly or indirectly involved with the fruit industry and the annual turnover of about 1500-2000 crore rupees.

Fruits of sweet cherry are refreshing, diuretic, energetic, anti-infective and have the laxative and detoxifying effect. For this reason maximum portion of cherry fruit is consumed in fresh form, although it is also processed in various forms like confectionary, ice creams, bakery, juice making, syruping and liquors. Cherries are rich source of proteins, sugars, having more calorific value than apple. Fresh cherries contain 78-85 per cent moisture, 0.5 to 1.2 per cent proteins, 0.2 per cent fat and 8.5 to 18.5 per cent sugars. Cherries are good source of vitamins and minerals like potassium, calcium, magnesium, iron and zinc (7). Concerning the fact that the demand for sweet cherry fruits increases from year to year, in perspective, there are real conditions to expand the production, and at the same time to enlarge its economic significance. An increase in production of sweet cherries, as well as profitability of its growing, depends on biological and economic properties of the cultivar and the rootstock.

\section{Materials and Methods}

The present investigation was conducted in three districts of Jammu and Kashmir state namely Srinagar, Baramulla and Shopian; located between $34^{0} 05^{\prime} 24^{\prime \prime}$ North Latitude and $74^{\circ} 47^{\prime} 24^{\prime \prime}$ East Latitude; $34^{0} 0^{\prime} 34^{\prime \prime}$ North Latitude and $74^{\circ} 0^{\prime} 45^{\prime \prime}$ East Latitude; $33^{\circ} 43^{\prime}$ $06^{\prime \prime}$ North Latitude and $74^{\circ} 50^{\prime} 01^{\prime \prime}$ East Latitude respectively. The districts under survey viz. Srinagar, Baramulla and Shopian 
are located at an altitude of 1585, 1593 and $2058.61 \mathrm{~m}$ above mean sea level respectively. The survey was conducted for two years 2013 and 2014 and observations were recorded as per the International Union for the Protection of New Varieties of plant standard descriptor (8). The data presented is pooled date of two years 2013 and 2014. Accessions selected during the initial survey at different locations of the three districts were tagged with aluminum labels. The basic material for the experiment consisted of 110 diverse genotypes of cherry selected during the survey on the basis of genetic variability for various morphological and phenological traits as per the International Union for the Protection of New varieties of plants (UPOV) standard descriptor (2006). The final experimental material comprised of 45 genotypes. The fruits were evaluated for different quality parameters. Total soluble solids were recorded by using hand refractometer at room temperature and readings are presented in Brix. The juice of each genotype was extracted by a blender and preserved in glass beaker separately. The juice was then analyzed for juice content \%, acidity (\%) using titration method as per the (A.O.A.C., 2000). Tocher's method was used for assigning various varieties to different clusters. The spatial distances between clusters were arrived at by taking square root of average intra and inter cluster $\mathrm{D}^{2}$ values.

\section{Results and Discussion}

Fruit weight is considered to be a very important trait in the fresh-market group; fruit shape is very important for packaging and transportation; fruit size is very important for the canning industry; and sugar content and total soluble solids content are very important for the food industry. Fruit size is an important factor in consumer liking and acceptance as bigger fruits are generally considered to be more attractive to the eye and therefore sell more easily and usually at a higher price per gram, so varieties yielding larger fruits will be preferred commercially. At the international level, cherry cultivars with large fruits are increasingly valued $(9,10)$ Perusal of the data regarding various quality parameters presented in Table 1, revealed highly significant differences among the genotypes for all the traits under study. The range of variation was highest for fruit weight to stone ratio (9.67-22.68) followed by TSS (13.2-22.0 ${ }^{0}$ Brix), fruit weight $(3.15-11.68 \mathrm{~g})$ and fruit volume $\left(2.35-10.49 \mathrm{~cm}^{3}\right)$. Similar observations have been found (11). Fruit size is expressed in this study by fruit weight which is mainly depended on the cultivar. Its influence was partly connected with the level of fruit set but particular climatic conditions of each year seem to be more important in this respect. Maximum fruit weight (11.68 g) and minimum fruit weight $(3.15 \mathrm{~g})$ was recorded in $\mathrm{KC}-37$ and $\mathrm{KC}-38$ respectively.

Fruit volume followed same pattern as that of fruit weight. Maximum fruit volume (10.49 $\mathrm{cm}^{3}$ ) was recorded in case of $\mathrm{KC}-37$ and minimum $\left(2.33 \mathrm{~cm}^{3}\right)$ in case of $\mathrm{KC}-30$. The diversity in fruit weight and fruit volume of various genotypes may be due to difference in cell size and cell densities. The stone size of the studied cherry genotypes ranged from $0.36-0.77 \mathrm{~g}$, while as fruit: stone ratio was between 9.67 and 22.68 .

Chemical composition aspects of fruits like total soluble solids and acidity provide important information to the consumers in terms of recognizing a more nutritious fruit (Fig. 1). The data is presented in Table 1. Perusal of the pooled data from two years of study showed a considerable variability on TSS. The maximum TSS $\left(22.6{ }^{\circ} \mathrm{B}\right)$ was recorded in $\mathrm{KC}-37$ whereas; minimum TSS $\left(13.1^{\circ} \mathrm{B}\right)$ was recorded in $\mathrm{KC}-39$. Environmental factors such as temperature, light (duration and intensity), rainfall/supply 
of water and locations have a pivotal role on the TSS (12). Trees with high moisture availability showed less TSS compared to scare water supply with higher contents of soluble solids in fruits. This indicates that the variability in fruit characteristics especially in fruit composition was not only genetic factor but also influenced by climatic factors. Maximum acidity $(0.96 \%)$ was recorded in KC-9, while lowest acidity (0.33\%) was recorded in $\mathrm{KC}-16$. The variation in fruit acidity may be due to different rates of conversion of organic acids into soluble sugars by different genotypes.

Fig.1 Mean values for fruit quality parameters of Kashmiri cherry accessions

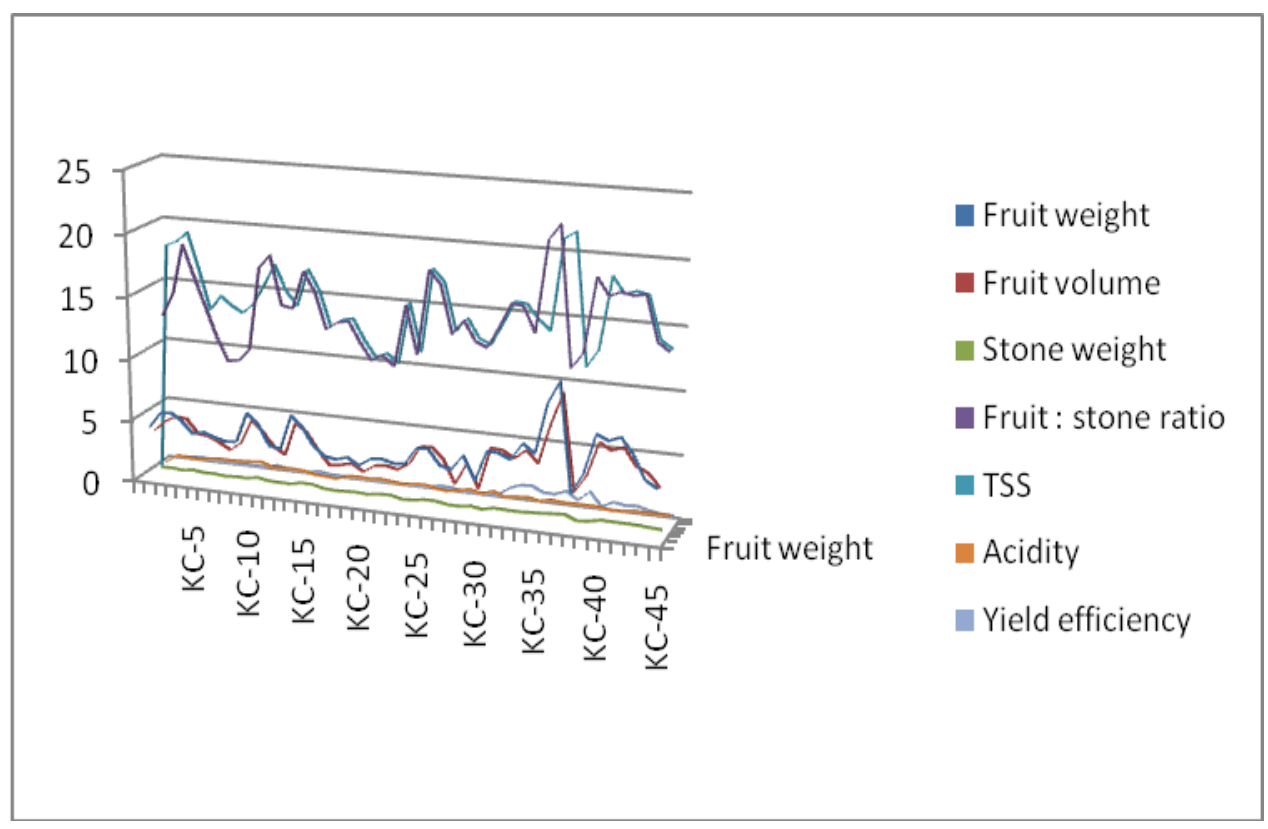

Fig.2 Cluster means for various traits in different clusters of Kashmiri cherry accessions

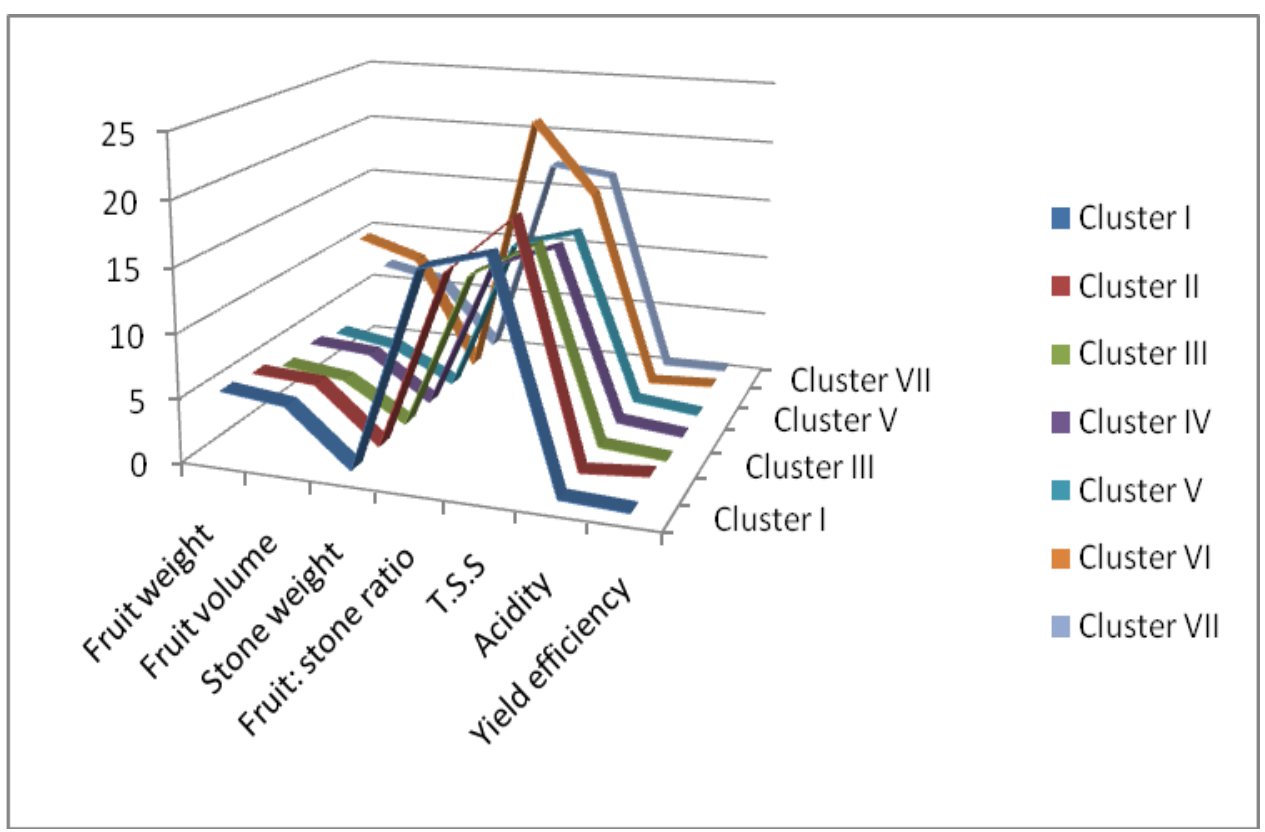


Fig.3 Dendrogram based on quality parameters of forty five cherry (Prunus avium L.) accessions

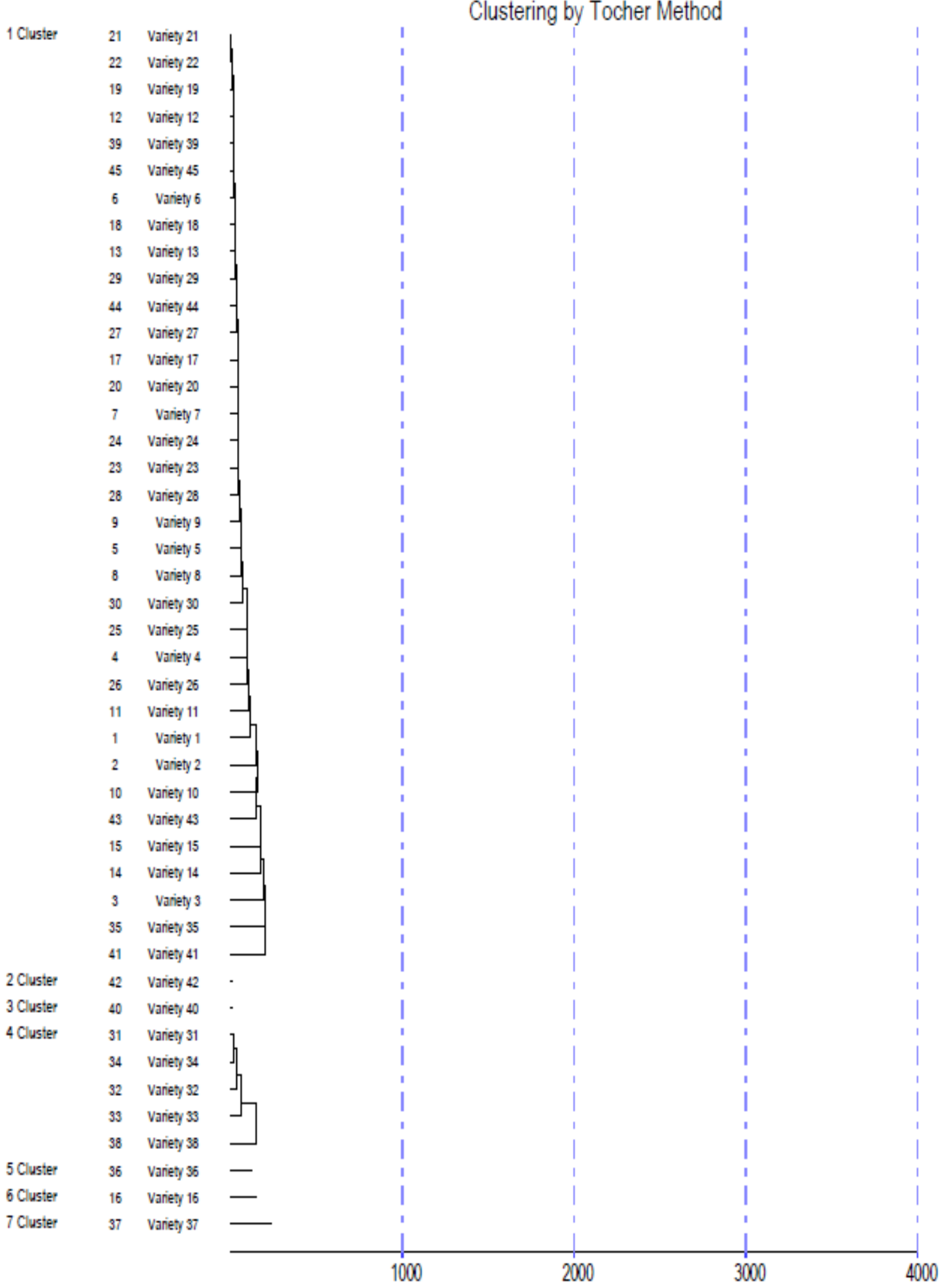


Table.1 Mean values for fruit quality parameters of Kashmiri cherry accessions

\begin{tabular}{|c|c|c|c|c|c|c|c|}
\hline $\begin{array}{l}\text { Accession } \\
\text { Name }\end{array}$ & Fruit weight & $\begin{array}{c}\text { Fruit } \\
\text { volume }\end{array}$ & $\begin{array}{c}\text { Stone } \\
\text { weight }\end{array}$ & $\begin{array}{c}\text { Fruit : } \\
\text { stone ratio }\end{array}$ & $\begin{array}{l}\text { TSS } \\
\left({ }^{0} \mathbf{B}\right)\end{array}$ & $\begin{array}{c}\text { Acidity } \\
(\%)\end{array}$ & $\begin{array}{c}\text { Yield } \\
\text { efficiency }\end{array}$ \\
\hline KC- 1 & 4.50 & 3.98 & 0.56 & 12.86 & 18.3 & 0.64 & 0.24 \\
\hline $\mathrm{KC}-2$ & 5.70 & 4.79 & 0.59 & 14.68 & 18.7 & 0.62 & 0.34 \\
\hline KC-3 & 5.83 & 5.24 & 0.51 & 18.72 & 19.5 & 0.55 & 0.38 \\
\hline KC-4 & 5.27 & 5.15 & 0.63 & 16.25 & 16.6 & 0.70 & 0.29 \\
\hline KC-5 & 4.33 & 4.06 & 0.52 & 13.90 & 13.4 & 0.79 & 0.23 \\
\hline KC-6 & 4.56 & 3.95 & 0.54 & 11.54 & 14.6 & 0.77 & 0.24 \\
\hline KC-7 & 4.23 & 3.54 & 0.45 & 9.67 & 13.9 & 0.81 & 0.22 \\
\hline KC-8 & 4.01 & 3.03 & 0.52 & 9.78 & 13.4 & 0.87 & 0.24 \\
\hline KC-9 & 4.10 & 3.73 & 0.51 & 10.76 & 14.2 & 0.96 & 0.21 \\
\hline KC-10 & 6.50 & 5.66 & 0.67 & 17.39 & 15.8 & 0.64 & 0.48 \\
\hline KC-11 & 5.75 & 4.82 & 0.51 & 18.47 & 17.5 & 0.66 & 0.33 \\
\hline KC-12 & 4.12 & 3.72 & 0.49 & 14.58 & 15.5 & 0.70 & 0.25 \\
\hline KC-13 & 3.92 & 3.19 & 0.48 & 14.40 & 14.4 & 0.63 & 0.24 \\
\hline KC-14 & 6.71 & 5.91 & 0.68 & 17.41 & 17.4 & 0.45 & 0.39 \\
\hline KC-15 & 5.92 & 5.15 & 0.67 & 15.88 & 15.8 & 0.42 & 0.27 \\
\hline KC-16 & 4.50 & 3.86 & 0.45 & 13.00 & 13.0 & 0.33 & 0.25 \\
\hline KC-17 & 3.75 & 2.76 & 0.39 & 13.65 & 13.6 & 0.65 & 0.27 \\
\hline KC-18 & 3.64 & 2.89 & 0.43 & 13.80 & 13.8 & 0.71 & 0.23 \\
\hline KC-19 & 3.90 & 3.13 & 0.48 & 12.23 & 12.2 & 0.65 & 0.24 \\
\hline KC-20 & 3.35 & 2.56 & 0.41 & 10.91 & 10.9 & 0.74 & 0.22 \\
\hline KC-21 & 3.99 & 3.17 & 0.56 & 11.35 & 11.3 & 0.64 & 0.24 \\
\hline KC-22 & 4.11 & 3.27 & 0.58 & 10.63 & 10.6 & 0.57 & 0.23 \\
\hline KC-23 & 3.85 & 3.08 & 0.36 & 15.50 & 15.5 & 0.65 & 0.21 \\
\hline KC-24 & 3.92 & 3.60 & 0.42 & 11.72 & 11.7 & 0.72 & 0.23 \\
\hline KC-25 & 5.27 & 5.09 & 0.56 & 18.36 & 18.3 & 0.52 & 0.43 \\
\hline KC-26 & 5.34 & 5.17 & 0.56 & 17.39 & 17.3 & 0.44 & 0.37 \\
\hline KC-27 & 4.15 & 4.27 & 0.39 & 13.61 & 13.6 & 0.62 & 0.23 \\
\hline KC-28 & 3.92 & 2.48 & 0.37 & 14.76 & 14.7 & 0.77 & 0.22 \\
\hline KC-29 & 5.14 & 4.22 & 0.51 & 13.20 & 13.2 & 0.58 & 0.31 \\
\hline KC-30 & 3.25 & 2.33 & 0.36 & 12.82 & 12.8 & 0.87 & 0.25 \\
\hline KC-31 & 5.67 & 5.63 & 0.58 & 14.52 & 14.5 & 0.52 & 0.89 \\
\hline KC-32 & 5.65 & 5.58 & 0.55 & 16.39 & 16.3 & 0.63 & 1.27 \\
\hline KC-33 & 5.25 & 5.04 & 0.52 & 16.26 & 16.2 & 0.71 & 1.35 \\
\hline KC-34 & 6.60 & 5.78 & 0.58 & 14.31 & 15.1 & 0.52 & 0.91 \\
\hline KC-35 & 5.91 & 4.87 & 0.62 & 21.42 & 14.3 & 0.73 & 0.88 \\
\hline KC-36 & 9.90 & 8.05 & 0.71 & 22.68 & 21.4 & 0.63 & 1.24 \\
\hline KC-37 & 11.68 & 10.49 & 0.77 & 11.85 & 22.0 & 0.66 & 0.62 \\
\hline KC-38 & 3.15 & 2.96 & 0.38 & 13.11 & 11.8 & 0.65 & 1.43 \\
\hline KC-39 & 4.78 & 4.34 & 0.47 & 18.96 & 13.2 & 0.64 & 0.33 \\
\hline KC-40 & 7.94 & 7.03 & 0.67 & 17.60 & 18.9 & 0.49 & 0.81 \\
\hline KC-41 & 7.53 & 6.51 & 0.65 & 17.99 & 17.6 & 0.52 & 0.65 \\
\hline KC-42 & 7.90 & 6.85 & 0.65 & 17.79 & 17.9 & 0.64 & 0.73 \\
\hline KC-43 & 6.71 & 5.55 & 0.63 & 17.96 & 17.7 & 0.65 & 0.48 \\
\hline KC-44 & 4.86 & 5.09 & 0.57 & 14.48 & 14.4 & 0.63 & 0.33 \\
\hline KC-45 & 4.33 & 4.07 & 0.51 & 13.83 & 13.8 & 0.66 & 0.31 \\
\hline Mean & 5.23 & 4.57 & 0.53 & 14.79 & 14.79 & 0.64 & 0.45 \\
\hline Range & $3.15-11.68$ & $2.33-10.49$ & $0.36-0.77$ & $9.67-22.68$ & $13.1-22.0$ & $0.33-0.96$ & $0.21-1.43$ \\
\hline $\mathrm{CV}$ & 2.42 & 3.77 & 1.71 & 2.88 & 0.73 & 3.14 & 4.39 \\
\hline
\end{tabular}


Table.2 Distribution of different cherry accessions into clusters based on $\mathrm{D}^{2}$ statistics

\begin{tabular}{lll}
\hline Cluster & $\begin{array}{l}\text { Number of genotypes } \\
\text { in the cluster }\end{array}$ & $\begin{array}{l}\text { Accession No. of the genotypes } \\
\text { I }\end{array}$ \\
\hline & 9 & KC-001, KC-002, KC-003, KC-004, KC-011, KC-015, \\
KC-025, KC-026, KC-029 \\
II & 6 & KC-016, KC-031, KC-032, KC-033, KC-034, KC-038 \\
III & 8 & KC-012, KC-013, KC-017, KC-019, KC-021, KC-022, \\
& 6 & KC-027, KC-039 \\
IV & 6 & KC-005, KC-006, KC-008, KC-009, KC-044, KC-045 \\
V & 7 & KC-007, KC-018, KC-020, KC-023, KC-024, KC-028, \\
& 2 & KC-030 \\
VI & 2 & KC-036, KC-0037 \\
VII & 7 & KC-010, KC-014, KC-035, KC-040, KC-041, KC-042, \\
& & KC-043 \\
\hline
\end{tabular}

Table.3 Average inter-cluster (above diagonal) and intra-cluster (diagonal) distance values among different Cherry (Prunus avium L.) genotypes

\begin{tabular}{|c|c|c|c|c|c|c|c|}
\hline Cluster & I & II & III & IV & V & VI & VII \\
\hline I & $\mathbf{3 1 0 . 2 3}$ & 637.63 & 759.45 & 1072.28 & 1838.59 & 1228.86 & 1933.45 \\
\hline II & & $\mathbf{0 . 0 0}$ & 32.04 & 704.95 & 407.93 & 1785.77 & 624.43 \\
\hline III & & & $\mathbf{0 . 0 0}$ & 643.17 & 337.92 & 1756.56 & 690.60 \\
\hline IV & & & & $\mathbf{2 9 6 . 0 8}$ & 945.85 & 1262.30 & 2415.80 \\
\hline V & & & & & $\mathbf{0 . 0 0}$ & 2776.24 & 823.53 \\
\hline VI & & & & & & $\mathbf{0 . 0 0}$ & 4076.06 \\
\hline VII & & & & & & & $\mathbf{0 . 0 0}$ \\
\hline
\end{tabular}

Table.4 Cluster means for various traits in different clusters of Cherry (Prunus avium L.) genotypes

\begin{tabular}{llllllll}
\hline Clusters & $\begin{array}{l}\text { Fruit } \\
\text { weight }\end{array}$ & $\begin{array}{l}\text { Fruit } \\
\text { volume }\end{array}$ & $\begin{array}{l}\text { Stone } \\
\text { weight }\end{array}$ & $\begin{array}{l}\text { Fruit: stone } \\
\text { ratio }\end{array}$ & T.S.S & Acidity & $\begin{array}{l}\text { Yield } \\
\text { efficiency }\end{array}$ \\
\hline Cluster I & 5.41 & 4.84 & 0.56 & 16.20 & 17.64 & 0.57 & 0.33 \\
Cluster II & 5.13 & 4.81 & 0.51 & 14.53 & 19.06 & 0.56 & 1.01 \\
Cluster III & 4.09 & 3.48 & 0.48 & 12.94 & 15.77 & 0.64 & 0.25 \\
Cluster IV & 4.36 & 3.99 & 0.52 & 12.38 & 14.32 & 0.78 & 0.26 \\
Cluster V & 3.74 & 2.92 & 0.40 & 12.74 & 14.20 & 0.75 & 0.22 \\
Cluster VI & 10.79 & 9.27 & 0.49 & 22.05 & 16.20 & 0.65 & 0.93 \\
Cluster VII & 7.03 & 6.05 & 0.65 & 17.35 & 16.72 & 0.59 & 0.63 \\
\hline
\end{tabular}

To assess the variability for these quality parameters, a dendrogram was constructed on the basis of mean values of two years data (Fig. 3). Mean, range values and coefficient of variance for each parameter is given in
Table 1. Based on the performance of various genotypes, forty five genotypes got grouped into seven clusters. Cluster-I comprised of maximum genotypes (9), followed by ClusterIII (8), Cluster-V (7), Cluster-VII (7), Cluster- 
II and Cluster-IV (6) and Cluster-VI (2). The names of the accessions in each cluster are given in the Table 2. Nine (KC-001, KC-002, $\mathrm{KC}-003$, KC-004, KC-011, KC-015, KC-025, $\mathrm{KC}-026, \mathrm{KC}-029)$ accessions fell in cluster I, six (KC-016, KC-031, KC-032, KC-033, KC034, KC-038) in cluster II, eight (KC-012, KC013, KC-017, KC-019, KC-021, KC-022, KC027, KC-039) in cluster III, six (KC-005, KC006, KC-008, KC-009, KC-044, KC-045) in cluster IV, seven (KC-007, KC-018, KC-020, $\mathrm{KC}-023, \mathrm{KC}-024, \mathrm{KC}-028, \mathrm{KC}-030$ ) in cluster $\mathrm{V}$, two (KC-036, KC-0037) in cluster VI and seven (KC-010, KC-014, KC-035, KC-040, $\mathrm{KC}-041, \mathrm{KC}-042, \mathrm{KC}-043$ ) in cluster VII.

The formation of different clusters with variable number of accessions indicates variability among accessions. Dendrogram illustrated variability at different levels between the accessions of different clusters and relatedness among the accessions within the same cluster. The pattern of group constellation revealed that geographical diversity was not an essential factor for clustering of genotypes from particular origin into a specific cluster. From this it can be concluded that although geographical diversity is very important but not the only criteria in determining the genetic divergence. Thus the grouping of various genotypes from different environments into a particular cluster can be attributed to the admixture or free exchange of plant material from one place to another. The perusal of the results revealed that Cluster-I had the maximum intra cluster distance (310.23) was observed in cluster-I, followed by Cluster-IV (296.08) (Table 3). Maximum inter cluster distance was found between Cluster-VI and Cluster-VII (4076.06), followed by Cluster-V and ClusterVI (2776.24), Cluster-IV and Cluster-VII (2415.80), Cluster-I and Cluster-VII (1933.45) and Cluster-I and Cluster-V (1838.59).

Cluster means for various quantitative traits are presented in Table 4 (Fig. 2). The perusal of data revealed that Cluster-I had a fruit weight of $5.41 \mathrm{~g}$, fruit volume of $4.84 \mathrm{~cm}^{3}$, stone weight of $0.56 \mathrm{~g}$, fruit: stone ratio of 16.20 , T.S.S of
$17.64{ }^{0}$ Brix, acidity of 0.57 per cent and yield efficiency of 0.33 . Cluster-II had a fruit weight of $5.13 \mathrm{~g}$, fruit volume of $4.81 \mathrm{~cm}^{3}$, stone weight of $0.51 \mathrm{~g}$, fruit: stone ratio of 14.53, T.S.S of $19.06{ }^{0}$ Brix, acidity of 0.56 per cent and yield efficiency of 1.01. Cluster-III had a fruit weight of $4.09 \mathrm{~g}$, fruit volume of $3.48 \mathrm{~cm}^{3}$, stone weight of $0.48 \mathrm{~g}$, fruit: stone ratio of 12.94, T.S.S of $15.77{ }^{0}$ Brix, acidity of 0.64 per cent and yield efficiency of 0.25 . Cluster-IV had a fruit weight of $4.36 \mathrm{~g}$, fruit volume of $3.99 \mathrm{~cm}^{3}$, stone weight of $0.52 \mathrm{~g}$, fruit: stone ratio of 12.38 , T.S.S of $14.32{ }^{0}$ Brix, acidity of 0.78 per cent and yield efficiency of 0.26 . Cluster-V had a fruit weight of $3.74 \mathrm{~g}$, fruit volume of $2.92 \mathrm{~cm}^{3}$, stone weight of $0.40 \mathrm{~g}$, fruit: stone ratio of 12.74 , T.S.S of $14.20{ }^{0} \mathrm{Brix}$, acidity of 0.75 per cent and yield efficiency of 0.22 .

Cluster-VI had a fruit weight of $10.79 \mathrm{~g}$, fruit volume of $9.27 \mathrm{~cm}^{3}$, stone weight of $0.49 \mathrm{~g}$, fruit: stone ratio of 22.05 , T.S.S of $16.20{ }^{0} \mathrm{Brix}$, acidity of 0.65 per cent and yield efficiency of 0.93. Cluster-VII had a fruit weight of $7.03 \mathrm{~g}$, fruit volume of $6.05 \mathrm{~cm}^{3}$, stone weight of 0.65 $\mathrm{g}$, fruit: stone ratio of 17.35 , T.S.S of 16.72 ${ }^{0}$ Brix, acidity of 0.59 per cent and yield efficiency of 0.63 . These findings are in agreement to those observed by (5), Lacis et al., (13,), Singh et al., (14,), Rai and Mishra (15), Lal et al., (16) and Nagar and Fageria (17) suggested selection of distant parents based on $\mathrm{D}^{2}$ analysis. Cluster means coupled with coefficient of variation depict the picture of genetic diversity (18). According to De et al., (19) traits contributing most towards divergence should be given greater emphasis for choosing the clusters for both direct selection as well as prospective hybridization scheme.

\section{References}

1. Ahmad, M F., Samanta, A. and Jabeen, A. 2010. Response of sweet cherry (Prunus avium L.) to fertigation of nitrogen, phosphorus and potassium under Kerawa lands of Kashmir valley. Indian Journal of Agricultural Sciences 80(6): 512-516 
2. Ahmed, M. 2008. Biodiversity in pears (Pyrus spp.): characterization and conservation of germplasm from Azad Jammu and Kashmir. $\mathrm{Ph}$. D. thesis submitted to Department of Horticulture University College of Agriculture Bahauddin Zakariya University Multan.

3. Anonymous, 1974, Gazetteer of Kashmir and Ladakh, Vivek Publishing House, Delhi.

4. Anonymous, 2007. Available from http://www.uga.edu/fruit/ cherry.htm.f

5. De, R.N., Seetharaman, R., Sinha, M.K. and Banerjee, S.P. 1988. Genetic divergence in rice. Indian Journal of Genetics and Plant Breeding 48(2): 189-194

6. Janes, H., Ardel, P., Kahu, K., Kelt, K. and Kikas, A. 2010. Some biological properties and fruit quality parameters of new sweet cherry cultivars and perspective selections. Agronomy Research 8(Special Issue III): 583 588.

7. Kabu, K.L., Dalal, M.A. and Singh, T. 1982. A note on cherry distribution in Jammu and Kashmir. Horticulture Research Reporter 2: 48-52.

8. Lacis, L., Edite, K., Viktor, T. and Rashal, I. 2009. Morphological variability and genetic diversity within Latvian and Swedish sweet cherry collections. Acta Universitatis Latviensis 753: 19-32.

9. Lal, R.K., Khanuja, S.P.S. and Misra, H.P. 2006. Genetic diversity in fennel (Foeniculum vulgare Miller). Indian Jornal of Genetics 66: 65-66.

10. Lichev, V., Govedarov, G., Tabakov, S. and Yordanov, A. 2004. Evaluation of sweet cherry cultivars recently introduced into Bulgaria compared with two Bulgarian cultivars. J. Fruit Ornament. Plant Res. 12: 281-285.
11. Long, L.E., Nunez-Elisea, R. and Cahn, H. 2008. Evaluation of sweet cherry cultivars and advanced selections adapted to the Pacific Northwest, USA. Acta Hortticulture 795: 255-260.

12. Lyngstad, L. and Sekse, L. 1996. Economic aspects of developing a high quality sweet cherry products in Norway. Acta Horticulture 379: 313-320.

13. Nagar, B.L. and Fageria, M.S. 2006. Genetic divergence in lehsua (Cordia myxa Roxb.). Indian Journal of Genetics 66: 67-68.

14. Rai, D. and Misra, K.K. 2005. Studies on genetic divergence in bael (Aegle marmelos Correa). Indian Journal of Horticulture 62: 152-54.

15. Randhawa, S.S. 1991. Cherries. In: Temperate Fruits. S.K. Mitra, T.K. Bose and D.S. Rathore (Eds.). Horticulture and Allied Publishers, Calcutta, India, pp. 309-343.

16. Sardana, S., Borthakur, D.N. and Lakhanpal, T.N. 1997. Genetic divergence in rice germplasm of Tripura. Oryzae 34(3): 201-208.

17. Singh, R., Meena, K.K. and Singh, S.K. 2003. Genetic divergence for yield and its component traits in pomegranate (Prunica granatum L.). Indian Journal of Plant Genetic Resources 16: 133-34.

18. Srivastava, K.K., Verma, M.K., Ahmad, N., Razvi, S.M. and Ahmad, S. 2014. Genetic variability and divergence analysis in sweet cherry (Prunus avium L.). Indian $J$. Horticulture 71(2): 156-161.

19. UPOV, 2006. Cherry descriptor (Guidelines for the conduct of tests for distinctness, uniformity and stability, International Union for the Protection of New Varieties of Plants. TG/35/7

\section{How to cite this article:}

Jahangeer A. Baba, W.M. Wani, R.A. Wani, Umar Iqbal, S.A. Hakeem, Z.A. Dar, Y.A. Basu, S. Bashir, S. Nissa, A.Y. Baba, Rafiya Mushtaq, Rehana Javid and Najeeb Mughal. 2017. Genetic Variability Studies in Fruit Quality Parameters of Kashmiri Cherry (Prunus avium L.). Int.J.Curr.Microbiol.App.Sci. 6(11): 2469-2477. doi: https://doi.org/10.20546/ijcmas.2017.611.290 